\begin{tabular}{|c|c|}
\hline \multirow{3}{*}{ 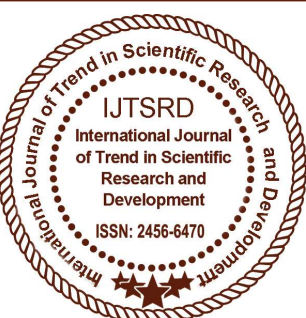 } & $\begin{array}{l}\text { International Journal of Trend in Scientific } \\
\text { Research and Development (IJTSRD) }\end{array}$ \\
\hline & Access Journal \\
\hline & ISSN No: 2456 - 6470 | www.ijtsrd.com | Volume - 2 | Issue - 1 \\
\hline
\end{tabular}

\title{
Activity of soil protease enzyme as influenced by dimethomorph and pyraclostrobin fungicides to groundnut (Arachis hypogaea L.) soil.
}

\author{
P. Ramanamma \\ Research Scholar, Department of Microbiology, Sri \\ Krishna Devaraya University, Anantapuramu, \\ Andhra Pradesh, India
}

\author{
V. Rangaswamy \\ Professor, Department of Microbiology, Sri Krishna \\ Devaraya University, Anantapuramu, \\ Andhra Pradesh, India
}

\section{ABSTRACT}

Soil microbial diversity is indispensable to maintain functional diversity and enzyme-mediated critical soil processes that detoxify soil from environmental pollutants, like pesticides. Thus, the present study was carried out to assess the effect of different concentrations of the fungicides on the activity of protease, in clay and sandy loam groundnut soils of Anantapuramu District of Andhra Pradesh, India. The use of pesticides in agriculture has highly increased during the last 40 years to increase crop yields. However, today most pesticides are polluting water, soil, atmosphere and food. Pesticides are also impact soil enzymes, which are essential catalysts ruling the quality of soil life. A laboratory experiment was conducted to study the effect of selected fungicides, dimethomorph and pyraclostrobin, at concentrations ranging from 0 to $10 \mathrm{~kg} \mathrm{ha}^{-1}$ on the activity of protease. The activities of protease were significantly more at pyraclostrobin and dimethomorph levels of 5.0 and 2.5 $\mathrm{kg} \mathrm{ha}{ }^{-1}$, respectively. But at higher concentrations of 7.5 and $10 \mathrm{~kg} \mathrm{ha}^{-1}$ respectively, dimethomorph and pyraclostrobin were toxic to protease activities. In soil samples receiving $2.5-5.0 \mathrm{~kg} \mathrm{ha}^{-1}$ of the fungcides, the accumulation of reducing sugar was pronounced more at 20 days, and the activity of the protease was drastically decreased with increasing period of incubation up to 30 and 40 days. The results of the present study thus, clearly, indicate that application of the Fungicides in cultivation of groundnut, at field application rates improved the activity of protease in soils.

\section{INTRODUCTION:}

Agriculture happens to be the backbone of Indian economy. It comprises major share in gross domestic production (GDP) and this sector is the largest employer in economy. On the contrary, 15-20\% of all crops are destroyed by pests every year (Bhalerao and puranik., 2009). Modern day agriculture greatly relies on the use of different group of pesticides in order to manage the crop pests and to gain a better crop yield (Quazi, R. Datta, D Sarkar., 2011). Agricultural management practices (e.g. crop rotation, mulching, burning, tillage and application of fertilizers and pesticides) have diverse effects on the various soil enzyme activities (Ajwa et al., 1999, Bandick and Dick 1999, Aon and Colaneri 2001, Xu et al., 2002). Groundnut (Arachis hypogaea L.) is one of the vastly produced oilseed crop, cultivated in more than 100 countries in the world, referred as a universal crop. India is one of the largest producers and consumer of groundnut in the world. Groundnut crop has major threat of pathogen infection that affect the groundnut production process from planting to storage (Singh \& Oswalt , 1992). The application of fungicides to soil to control plant diseases has become a common practice in crop production in many parts of the world. Pesticides can be classified in a number of ways: by target pest, their mode of action or chemical family. Several studies have shown that chemical products used in farming (e.g., fertilisers, pesticides, herbicides) have a marked influence on the soil enzyme activity (Alvear et al., 2006). The main chemical groups are organochlorine, organophosphate, carbamate, pyrethroids, triazine and sulfonylurea (Afify et al., 2010). In India, 
Anantapuramu District, a semiarid region of Andhra Pradesh, ranks first in the area of groundnut (Arachis hypogaea L.) cultivation, but its productivity is low and fluctuates around $9 \mathrm{q} / \mathrm{ha}^{-1}$ on average (Anonymous 2014). Enzymes in soils mainly come from plants, soil animals and microorganisms and connected covalently, crosslinked, copolymerized, adsorbed and included in the microcapsules of soil particles (Girish S., Ajit V., 2011). Soil enzyme activities vary seasonally and have been related to soil physico-chemical characters, microbial community structure, vegetation, disturbance and succession (Caldwell B.A. 2005). The biological and chemical proprieties of soil are very important in the biogeochemical cycles of nutrients, enzymes produced by soil microorganisms being responsible with biochemical transformations. Like other pesticides, fungicides are bio toxicants which interfere not only with the biochemical and physiological reactions of the target plant pathogens but may also influence populations or activity of other non target organisms in soil (Tu, C.M., 1992). Due to soil enzymes considered sensitive to disturbances in ecosystem (Zwikel et al., 2007), their activities were increased to different degrees by organic manure incorporation and gave a significant and positive relationship of enzyme activity with organic $\mathrm{C}$ and total $\mathrm{N}$ (Nayak et al., 2007). The physicochemical nature of the soil is important for persistence, metabolism and binding of pesticides in the soil (Burns, R.G 1982). An ideal pesticide should be toxic to the only target organism, biodegradable and should not leach in to ground water. The presence of enzymes in soil depends on their continuous release by organisms inhabiting the soil ecosystem (Burns, 1982; Han et al., 2010). The study of enzyme activity of soils may reflect the potential capacity of a soil to perform certain biological transformations of importance to soil fertility. The present work thus aimed at finding out the effect of very widely used fungicides in Indian agricultural system on activity of various soil enzymes at the recommended and higher dosages. The aim of the study was to determine the effects of the fungicides on the activity of soil enzyme protease.

\section{SCOPE OF THE STUDY}

The objective of the study is to determine the behavior of dimethomorph and pyraclostrobin in both soils and to evaluate the responses of soil enzymes. This information will be useful for predicting the environmental fate of these widely used fungicides for continuous use and for understanding the potential adverse effects of intensive treatment with dimethomorph and pyraclostrobin on soil protease activity.

\section{MATERIALS AND METHODS}

\subsection{Soils used in the present study:}

Agricultural soil samples such as samples of black clay soil and red sandy loam soil, collected from groundnut cultivated fields of Anantapuramu District of Andhra Pradesh, India in a semi arid zone from the depth of 12 $\mathrm{cm}$ and mixed thoroughly to prepare a homogenate composite sample. Soil samples air dried at room temperature, were cleaned by removing plant material and other debris and passed through a $2 \mathrm{~mm}$ sieve and stored at $4^{\circ} \mathrm{c}$ prior to analysis.

\subsection{Analysis of Physico- chemical characteristics of soil samples:}

Mineral matter of soil samples such as sand, silt and clay contents were analyzed with the use of different sizes of sieves by following the method of Alexander (1961). Water holding capacity of the soil samples were determined by adding distilled water up to the saturation point and then $60 \%$ water holding capacity of the soil samples was calculated by Johnson and Ulrich (1960). $\mathrm{pH}$ of soil samples was determined by mixing soil and water in the ratio of $1: 1.25$ using systronics digital $\mathrm{pH}$ meter with calomel glass electrode. Organic carbon content in soil samples was estimated by Walkey-Black method and the organic matter was calculated by multiplying the values with 1.72 (Jackson, 1971). Electrical conductivity of soil samples was measured by a conductivity bridge. Total nitrogen content in soil samples was determined by the method (Jackson, 1971). The inorganic ammonium nitrogen content in the soil samples after extraction of $1 \mathrm{M} \mathrm{KCl}$ by Nesslerization method (Jackson, 1971) and contents of nitrite nitrogen (Barnes and Folkard, 1951), and the contents of nitrate-nitrogen by Brucine method (Ranney and Bartlett, 1972) after extraction with distilled water were determined respectively.

Physico-chemical characters of the two soil samples are listed in table 1. 


\subsection{Table1 Physico-chemical properties of the soils}

\begin{tabular}{|l|l|l|}
\hline Properties & Black clay soil & Red sandy loam soil \\
\hline Sand (\%) & 66.4 & 52.4 \\
\hline Silt (\%) & 23.6 & 26.9 \\
\hline Clay (\%) & 9.3 & 19.4 \\
\hline pH $^{\text {a }}$ & 7.9 & 7.1 \\
\hline Water holding capacity (ml g-1 soil) & 0.45 & 0.32 \\
\hline Organic matter (\%) b & 1.44 & 0.74 \\
\hline Total nitrogen (\%) $^{\mathrm{c}}$ & 0.089 & 0.048 \\
\hline $\mathrm{NH}_{4}^{+}-\mathrm{N}\left(\mu \mathrm{g} \mathrm{g}^{-1}\right.$ soil $^{\mathrm{d}}$ & 8.57 & 7.02 \\
\hline $\mathrm{NO}_{2}^{-} \mathrm{N}\left(\mu \mathrm{g} \mathrm{g}^{-1}\right.$ soil $^{\mathrm{e}}$ & 0.45 & 0.66 \\
\hline $\mathrm{NO}_{3}^{-} \mathrm{N}\left(\mu \mathrm{g} \mathrm{g}^{-1} \text { soil }\right)^{\mathrm{f}}$ & 0.92 & 0.74 \\
\hline
\end{tabular}

${ }^{\mathrm{a}} 1: 1.25=$ soil: water slurry

${ }^{\mathrm{b}}$ Walkley- Black method (Johnson and Ulrich, 1960)

${ }^{\mathrm{c}}$ Micro-Kjeldahl method (Johnson and Ulrich, 1960)

${ }^{\mathrm{d}}$ Nesslerization method (Johnson and ulrich, 1960)

${ }^{\mathrm{e}}$ Diazotization method (Ranney and Bartlett, 1972)

${ }^{\mathrm{f}}$ Brucine method (Barnes and Folkard, 1951)

\section{Fungicides used in the present study :}

To determine the influence of selected fungicides on soil enzyme activities, Pyraclostrobin Chemical Name (IUPAC): methyl $N-(2-\{[1-(4-$ chlorophenyl)-1Hpyrazol-3- $\quad$ yl]oxymethyl $\}$ phenyl)- $N$-methoxy carbamate. Pyraclostrobin is very effective against leaf spot diseases (18), but high rates $(0.21$ to $0.27 \mathrm{~kg} / \mathrm{ha})$ are also recommended for control of stem rot (Kemerait, B., Brenneman, T., and Culbreath, A. 2006). Dimethomorph (Chemical Name: 4-(3-(4chlorophenyl)-3-(3,4-dimethoxy phenyl) acryloyl)morpholine). Therefore, this study aimed to induce systemic resistance in groundnut by foliar application of fungicides to protect the crop from opportunistic pathogen and yield losses. commercial fungiicides were dissolved in distilled water.

\section{SOIL INCUBATION STUDIES}

\section{Protease activity}

For determination of protease activity, two grams of soil samples were distributed in test tubes $(12 \times 150$ $\mathrm{mm}$ ) and treated with the selected fungicide to provide final concentration of $10,25,50,75$ and $100 \mu \mathrm{g} \mathrm{g}^{-1}$ soil which are equal to $1.0,2.55 .07 .5$ and $10.0 \mathrm{~kg} \mathrm{ha}^{-1}$ of field application rates in order to maintain wáter holding capacity (WHC), about $2 \mathrm{Ml}$ of deionized water was added to test tubes containing black soil and $1 \mathrm{Ml}$ into tubes containing red soil. Untreated soil samples served as control. All the test tubes including controls were incubated in the laboratory at room temperature $\left(28 \pm 4^{\circ} \mathrm{C}\right)$ for $10,20,30$ and 40 days. After incubation, triplicate soil samples were withdrawn for the assay of protease as adopted by Speir and Ross 1975, also similar method was followed by Rangaswamy et al. and Jayamadhuri 2004 


\section{Assay of soil protease}

Soil samples including controls were incubated with 10 $\mathrm{ml}$ of $0.1 \mathrm{M}$ tris (2-amino-2 (hydroxyl methyl) propane1:3-diol) ( $\mathrm{pH} 7.5)$ containing sodium caseinate $(2 \%$ $\mathrm{w} / \mathrm{v}$ ) for $24 \mathrm{hrs}$ at $30^{\circ} \mathrm{C}$. An aqueous solution of trichloro acetic acid $(4 \mathrm{ml}, 17.5 \% \mathrm{w} / \mathrm{w})$ was then added and the mixer was centrifuged. The supernatant liquid, in suitable aliquots, was treated with $3 \mathrm{ml}$ of $1.4 \mathrm{M}$ $\mathrm{Na}_{2} \mathrm{CO}_{3}$ and $1 \mathrm{ml}$ of Folin-Ciocalteau reagent $(33.3 \%$ $\mathrm{v} / \mathrm{v})$ with rapid swirling. The blue colour, thus formed after 30 minutes, was read at $700 \mathrm{~nm}$ in a Spectrophotometer. Tyrosine equivalents in soil extracts were estimated by referring to a calibration curve prepared with known concentration of tyrosine.

\section{Statistical analysis}

The concentration of protease was calculated on the basis of soil weight (oven dried). Data were analysed using one-way ANOVA and the differences contrasted using Duncan's multiple range test (DMRT) (Jaffer et al., 2010). All statistical analysis was performed at using SYSTAT Statistical software package.

\section{RESULTS AND DISCUSSION}

Groundnut (Arachis hypogaea L.) is predominantly grown in both black and red clay soils of Anantapuramu district, Andhra Pradesh, India. Proteases in soil plays a significant role in nitrogen mineralization, more active in soils with a high water and humus content forest soils and landfills. Activity of this enzyme does not depend on microbial community of soils and expresses the biological activity of the soil. During last decades, pesticides were increasingly used in agriculture in order to limit crop diseases and increase food production. Over the years, increased crop productivity has lead into the use of many kinds of fungicides. Constant and indiscriminate use of these fungicides poses greater risk to soil health. Our analysis revealed that protease activity was depressed at higher concentrations ( 7.5 and $10.0 \mathrm{~kg} \mathrm{ha}^{-1}$ ) of dimethomorph and pyraclistrobin treated soils than untreated controls throughout the experiment (Table 2) suggesting that the enzyme is rather sensitive to dimethomorph and pyraclistrobin. The activities of protease were significantly more at pyraclostrobin and dimethomorph levels of 5.0 and $2.5 \mathrm{~kg} \mathrm{ha}^{-1}$, respectively. But at higher concentrations of 7.5 and $10 \mathrm{~kg} \mathrm{ha}^{-1}$ respectively, dimethomorph and pyraclostrobin were toxic to protease activities. In soil samples receiving $2.5-5.0 \mathrm{~kg}$ $\mathrm{ha}^{-1}$ of the fungcides, the accumulation of reducing sugar was pronounced more at 20 days, and the activity of the protease was drastically decreased with increasing period of incubation up to 30 and 40 days.The results of the present study thus, clearly, indicate that application of the Fungicides in cultivation of groundnut, at field application rates improved the activity of protease in soils. The stimulatory concentration was noticed for dimethomorph and puraclostrobin 2.5 and $5.0 \mathrm{~kg} \mathrm{ha}^{-1}$. Rasool and Zafar Reshi (2010) noticed the stimulatory effect on protease activity in comparison with the control up to 21 days of incubation. Similar observations on protease activity in soil treated with monocrototphos, quinalphos, cypermethrin and fenvelerate up to $25 \mathrm{ppm}$ level was recorded by Rangaswamy et al., (1994). Endo et al. (1982) observed that stimulation of protease activity in a native soil was reported after treatment with Linuron at $10 \mathrm{mg} \mathrm{kg}^{-1}$, whereas Cartap-HCL at $100-1000 \mathrm{mg} \mathrm{kg}^{-}$ ${ }^{1}$ inhibited the enzyme activity without recovery during a period of 60 days. In accordance with the maximum increase in protease activity at $2.5 \mathrm{~kg} \mathrm{ha}^{-1}$ of dithane M45 and $5.0 \mathrm{~kg} \mathrm{ha}^{-1}$ of dhanustin and contaf in black and red soils of groundnut, Mohiddin et.al., (2011) noticed that two insecticides acephate and imidacloprid at 25 and $50 \mathrm{ppm}$ caused increment of $46-54 \%$ in the enzyme activity at 10 day interval respectively.

Table 2: Activity of protease* under the different concentrations of selected fungicides in black and Red soil for 24 hours after 10 days

\begin{tabular}{|l|l|l|l|l|}
\hline $\begin{array}{l}\text { Pesticide } \\
\text { concentration } \\
\left(\mathrm{kg} \mathrm{ha}^{-1)}\right.\end{array}$ & $\begin{array}{l}\text { Dimethomorph } \\
\text { Black Soil }\end{array}$ & $\begin{array}{l}\text { Pyraclostrobin } \\
\text { Black soil }\end{array}$ & $\begin{array}{l}\text { Dimethomorph } \\
\text { Red Soil }\end{array}$ & $\begin{array}{l}\text { Pyraclostrobin } \\
\text { Red Soil }\end{array}$ \\
\hline 0.0 & $327 \pm 3.356 \mathrm{~d}$ & $287+3.637 \mathrm{c}$ & $257 \pm 1.687 \mathrm{e}$ & $245+2.964 \mathrm{~d}$ \\
\hline 1.0 & $422 \pm 5.362 \mathrm{~b}$ & $238+4.237 \mathrm{~d}$ & $362 \pm 2.351 \mathrm{~b}$ & $284+5.791 \mathrm{c}$ \\
\hline 2.5 & $561 \pm 2.518 \mathrm{a}$ & $358+4.372 \mathrm{~b}$ & $463 \pm 9.651 \mathrm{a}$ & $307+4.733 \mathrm{~b}$ \\
\hline
\end{tabular}




\begin{tabular}{|l|l|l|l|l|}
\hline 5.0 & $390 \pm 4.681 \mathrm{c}$ & $432+7.165 \mathrm{a}$ & $356 \pm 5.863 \mathrm{c}$ & $381+7.132 \mathrm{a}$ \\
\hline 7.5 & $303 \pm 3.932 \mathrm{e}$ & $263+7.331 \mathrm{e}$ & $270 \pm 9.169 \mathrm{~d}$ & $236+3.468 \mathrm{e}$ \\
\hline 10.0 & $270 \pm 8.449 \mathrm{f}$ & $228+4.632 \mathrm{f}$ & $208 \pm 2.357 \mathrm{f}$ & $172+2.357 \mathrm{f}$ \\
\hline
\end{tabular}

${ }^{*} \mu \mathrm{g}$ tyrosine g-1 soil formed after 24 hours incubation at $30^{\circ} \mathrm{C}$ with $1 \%$ casein. Figures, in parentheses, indicate relative production percentages. Means, in each column, followed by the same letter are not significantly different $(P \leq 0.05)$ from each other according to DMR test.

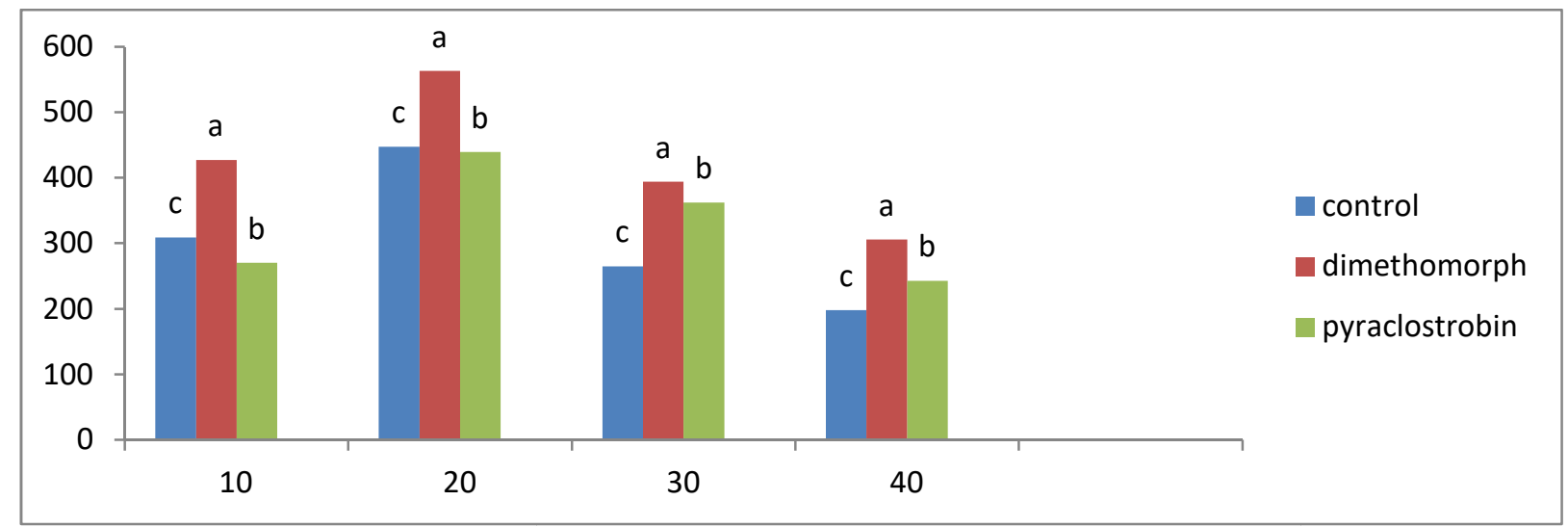

Influence of selected fungicides at 2.5 and $5.0 \mathrm{~kg} \mathrm{ha}^{-1}$ on protease* activity in black soil after $24 \mathrm{hours}$. ${ }^{*} \mu \mathrm{g}$ tyrosine $\mathrm{g}^{-1}$ soil formed after 24 hours incubation at $30^{\circ} \mathrm{C}$ with $1 \%$ casein. The values are the means \pm S.E. for each incubation periods, the means with different letters are significantly different $(P \leq 0.05)$ from each other according to DMR test.

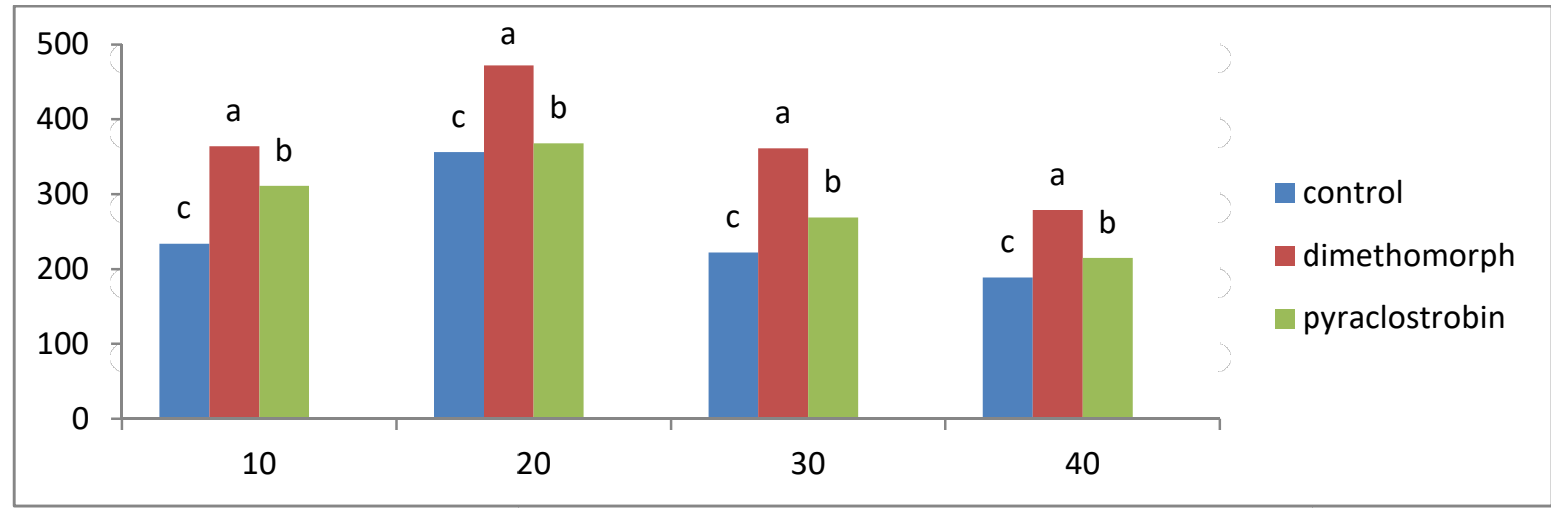

Influence of selected fungicides at 2.5 and $5.0 \mathrm{~kg} \mathrm{ha}^{-1}$ on protease* activity in red soil after 24 hours. ${ }^{*} \mu \mathrm{g}$ tyrosine $\mathrm{g}^{-1}$ soil formed after 24 hours incubation at $30^{\circ} \mathrm{C}$ with $1 \%$ casein. The values are the means \pm S.E. for each incubation periods, the means with different letters are significantly different $(P \leq 0.05)$ from each other according to DMR test.

\section{CONCLUSIONS}

The results of the present study thus, clearly indicated that the fungicides, dimethomorph and pyraclostrobin were profoundly enhanced the activity protease at 2.5. and $5.0 \mathrm{~kg} \mathrm{ha}^{-1}$. Based on the above results, it is concluded that the protease were not affected, by the fungicides applied at recommended levels in agricultural systems. No reports are available on the influence of dimethomorph and pyraclostrobin on protease activity in groundnut soils. Hence, further research is needed to evaluate the effect of these fungicides on soil enzyme activities.

\section{ACKNOWLEDGMENT}

The author (PR) are grateful to the University Grants Commission UGC-BSR, New Delhi, India, for financial assistance and at the same time we are very much thankful to the Department of Microbiology, Sri 
Krishna Devaraya University for providing all the necessary facilities in fulfilling our research.

\section{REFERENCES}

1. Afify A, Mohamed MA, El-Gammal HA, Attallah ER (2010) Multiresidue method of analysis for determination of 150 pesticides in grapes using quick and easy method (QuEChERS) and LCMS/MS determination. J Food Agric Environ 8:602-606.

2. Ajwa H.A., Dell C.J., Rice C.W. (1999): Changes in enzyme activities and microbial biomass of tallgrass prairie soil as related to burning and nitrogen fertilization. Soil Biology and Biochemistry, 31: 769-777.

3. Alexander M (1961) Introduction to soil Microbiology, Wiley Estern Ltd., New Delhi,472 pp.

4. Alvear, Z., Pino, B., Castillo, C., Trasar-Cepeda, C., Gil-Sotres, F. 2006. Efecto de la cero labranza sobre algunas actividades biológicas en un alfisol del sur de Chile. J.Soil Sc. Plant. Nutr. 6, 38-53.

5. Barnes, H., and Folkard, A.R. 1951. The determination of nitrites. Analyst, 76(907): 599 603.

6. Burns,R.G.: SoilBiol.Biochem. 14: 423-427 (1982).

7. Burns, R.G. 1982. Enzyme activity in soil: Location and a possible role in microbial ecology. Soil Biol. Biochem. 14, 423-427.

8. T.S. Bhalerao, P.R. Puranik, Biodegradation of organochlorine pesticide, endosulfan, by a fungal soil isolate Aspergillus niger. Int Biodeterior Biodegrad. 59 (2009) 315-319.

9. Caldwell B. A. (2005). Enzyme activities as a component of soil biodiversity: A review. Pedobiologia 49: 637-644.

10. Endo T, Taiki K, Nobutsura T, Michihiko S. Effect of insecticide cartaphydrochloride on soil enzyme activities, respiration and on nitrification. J. Pestic. Sci, 1982. 7, 101- 110.

11. Girish S., Ajit V. (2011). Soil Enzymology. 12 - 16.

12. Jackson ML (1971) Soil chemical Analysis, prentice Hall,New Delhi, India, pp 535-538.

13. Jaffer Mohiddin G, Srinivasulu M, Madakka M,
Rangaswamy V(2010). Influence of insecticides on the activity of amylase and celluase in groundnut (Arachis hypogea L.) Soil.Ecology, Environemt and conservation 16(3) 383-388.

14. Jaffer Mohiddin G, Srinivasulu M, Maddela N.R, Manjunatha B, Rangaswamy V, Alma Rosel Koch Kaiser, Jessica Cristina Mainsincho Asqui, Darwin Rueda, Environmental Monitoring and Assessment, 2015.]

15. Jayamadhuri R. Interactions between pesticides and microorganiams in soils from groundnut fields, Ph.D, Sri Krishnadevaraya University, Anantapur, 2004.

16. Johnsen, K., C.S. Jacobsn, V. Torsvik and J .Sorenson, 2001. Pesticide effects onBacterial diversity in Agricultural soils- A review. Biol. Feerti. Soils, 33:443-453.

17. Johnson, C.M., Ulrich, A. 1960. Determination of moisture in plant tissues. Calif. Agricult. Bull 766:112-115.

18. Kemerait, B., Brenneman, T., and Culbreath, A. 2006. Peanut disease control. Pages 126-127 in: Georgia Pest Management Handbook. P. Guillebeau, ed. Special Bul. 28, Univ. of Georgia, Athens, GA.

19. Kemerait, B., Brenneman, T., and Culbreath, A. 2010. 2010 peanut disease update. Pages 57-80 in: 2010 peanut update. J. P. Beasley, Jr., ed. Coop. Ext. Ser. Coll. Of Agric. Environ. Sci., Univ. of Georgia, GA.

20. Nayak D.R., Jagadeesh Babu Y., Adhya T.K. (2007): Long-term application of compost influences microbial biomass and enzyme activities in a tropical Aeric Endoaquept planted to rice under flooded condition. Soil Biology and Biochemistry, 39: $1897-1906$.

21. S. Quazi, R. Datta, D Sarkar, Effects of soil types and forms of arsenical pesticide on rice growth and development. Int $\mathrm{J}$ Environ Sci Technol. 8 (2011) 445-460.

22. Ranney, T.A., Bartlett, R.J. 1972. Rapid field determination of nitrate in natural waters. Common. Soil Sci.Plant Anal., 3: 183- 186.

23. Rangaswamy V, Reddy BR, Venkateswarlu K. Activities of dehydrogenase and protease in soil as 
influenced by monocrotophos, quinalphos, cypermethrin fenvalerate. Agric. Ecosys. Environ. 1994. 47, 319-326.

24. RANGASWAMY V., and VENKATESWARLU K.., 1992a: Activities of amylase and invertase as influenced by the application of monocrotophos, quinalphos, cypermethrin and fenvalerate to groundnut soils. Chemosphere, vol. 25(4), pp.525530 .

25. Rasool N, Zafar Reshi A. Effect of the fungicide mancozeb at different application rates on enzyme activities in a silt loam soil of the Kashmir Himalaya, India. Tropical Ecology, 2010. 51, 199205.

26. Singh F, Oswalt DC. 1992. Major diseases of groundnut. Skill development series no. 6.ICRISAT, Human Resource Development Program, International Crops Research Institute for the Semi-arid Tropics, Patancheru, Andhra Pradesh, India; p. 1-48.
27. SPEIR TW., and DJ., ROSS., 1975: Effects of storage on the activities of protease, urease, phosphatase and sulphatase in three soils under pasture. New Zealand Journal Science. vol. 18, pp. 231-237.

28. Tu, C.M., 1992. Effect of some herbicides on activities of microorganisms and enzymes in soil. J. Environ. Sci. Health, Part B 27: 695-709.

29. Zwikel S., Lavee H., Sarah P. (2007): Temporal dynamics in arylsulfatase enzyme activity in various microenvironments along a climatic transect in Israel. Geoderma, 140: 30-41. 